\title{
Shared Taxonomy for the Implementation of Responsible Innovation Approach in Industrial Ecosystems
}

\author{
Asta Valackiene $\dot{1}^{1}$ and Rafał Nagaj ${ }^{2, *(D)}$ \\ 1 Institute of Business and Economics, Faculty of Public Governance and Business, \\ Mykolas Romeris University, LT-08303 Vilnius, Lithuania; avala@mruni.eu \\ 2 Institute of Economics and Finance, University of Szczecin, 71-101 Szczecin, Poland \\ * Correspondence: rafal.nagaj@usz.edu.pl; Tel.: +48-502160109
}

check for updates

Citation: Valackienè, A.; Nagaj, R. Shared Taxonomy for the Implementation of Responsible Innovation Approach in Industrial Ecosystems. Sustainability 2021, 13, 9901. https://doi.org/10.3390/ su13179901

Academic Editors: Varun Gupta, Rainer Telesko, Maria Belén Usero Sánchez, Virginia Hernández Paz and Nadia Di Paola

Received: 30 July 2021

Accepted: 30 August 2021

Published: 3 September 2021

Publisher's Note: MDPI stays neutral with regard to jurisdictional claims in published maps and institutional affiliations.

Copyright: (c) 2021 by the authors Licensee MDPI, Basel, Switzerland. This article is an open access article distributed under the terms and conditions of the Creative Commons Attribution (CC BY) license (https:// creativecommons.org/licenses/by/ $4.0 /)$.

\begin{abstract}
Symbolic narratives, such as an "ivory tower", a "grey zone", or a "black box" tell us about the gap between university and society, and academia and industry. Recently, they have been replaced by the Quadruple Helix model, which closes the gap by connecting four main stakeholdersgovernment, university, industry, and society, into an innovation ecosystem. However, the roles of the different stakeholders are often blurred and difficult to define, and it is difficult to develop a basic approach to implement responsible innovations in industrial ecosystems in general. On the other hand, the interactions between stakeholder groups, especially universities and industry, are not sufficiently demonstrated in both scientific literature and empirical studies. We note that the responsible research and innovation (RRI) approach should facilitate a framework of shared taxonomy among stakeholders. By highlighting this situation, we follow the paradigm of emerging thinking and we seek to fill this knowledge gap theoretically and empirically. Therefore, in this study, we combined several strategies and perspectives. First, we conducted survey research concerning social capital in Poland and Lithuania to understand the impact of social capital and trust on stakeholder cooperation. Second, we conducted interviews with scientists who actively work to transfer knowledge into industry. Third, we utilized field notes from working experiences in research management. This work has theoretical and practical implications. The theoretical contribution of the paper demonstrates the construction of methodology based on emerging perspectives, and new theoretical insights, on professional discourses for implementing the responsible innovation approach in industrial ecosystems, by highlighting the commitments of main stakeholder groups. Practical input: our insights and empirical research will contribute toward sustainability policymaking and achieving substantial results in industrial ecosystems. The results indicate that if there is trust, then the government, companies, and society (in Poland and Lithuania) would be willing to cooperate with each other. However, there is a lack of trust and cooperation between universities and businesses. Stakeholders have become increasingly aware of the emergence of a science and industry cooperation as an open platform, enlarged with society and policies. They note the problem of making research public and transparent as part of a new mode of cooperation; however, they articulate RRI as a framework of shared taxonomy.
\end{abstract}

Keywords: responsible research and innovation; innovation ecosystem; quadruple helix model; social capital

\section{Introduction}

Discussing responsible innovation in the industrial ecosystem requires conceptual understanding, knowledge, and efficient solutions, highlighting the interaction among all four stakeholder groups-industry, government, academia, and society—and implementing responsible innovations in the process of cooperation in these groups. It should be noted that such discussions are exacerbated by unforeseen crises and social changes, as observed during the COVID-19 pandemic crisis [1-3]. Hence, many researchers are seeking to identify ways to achieve the sustainable development goals (SDG) (for post COVID-19) [4,5]. 
The above-mentioned aspects require strategic decisions and preparations to effectively manage the ecosystem. We should note that the interaction of all four components of the industrial ecosystem is a coherent (not a single) collaborative process, where we must separately assess the strength, importance, and effectiveness of social capital for each stakeholder group, highlighting the social commitments of each component, implementing responsible innovation both local and nationwide.

In order to validate this methodological position, we found a basis for developing innovation systems at the national, regional, and sectoral levels, to promote the research and innovation initiatives under the EU FP7 program. Therefore, new theoretical insights and practical examples of application, i.e., empirical analysis, ae required.

Furthermore, the conceptual and logical basis of our research is based on the emergent approach. We note the traditional methods (i.e., the Triple Helix model, which emphasizes trilateral networks, e.g., university; industry, government) and the new emergent methods (Quadruple Helix model, which emphasizes four networks, i.e., government/public; academic/universities; industry/firms, corporations; citizen/society), as well as the analysis of the following social phenomenon: implementing a responsible innovation approach in the industrial ecosystem.

Research level of scientific problem. As we stated above, the Quadruple Helix model "embeds" civil society into the Triple Helix model $[6,7]$. This gives innovation a social dimension and obliges other stakeholders, especially the scientific and industrial sectors, to consider societal needs in their activities. The notion that science and business should consider societal needs and values is not new. Wang [8] noted traces of social responsibility in the book "The Gospel of Wealth", written by Andrew Carnegie, the founder of the American Steel Group in 1899. Universities have long-lasting and strong traditions, cooperating with businesses and social partners. For example, the "Third Mission" represents the economic-social mission of universities and their contributions to communities. From the perspective of networking, in regard to the Quadruple Helix model design (an innovation helix framework describing university-industry-government-public-environment interaction within a knowledge economy, where knowledge is created and circulated as input and output, in a way that affects the natural environment and, thus, sustainable development), the following can be stated: this approach requires trade-offs between economic benefits, social progress, education-driven innovation, effective management, and sustainability. It is important to limit the trade-offs and emphasize socioecological interactions. Moreover, the collective interactions and implementation of the responsible innovation approach in industrial ecosystems, policymaking, and academic research should be justified.

This implies researcher engagement with society and the public (RESP), when traditional missions of research and teaching are integrated, with the aim of social economic development in the region or country. However, nowadays, university cooperation should be developed differently, i.e., by creating joint infrastructures, crowd sourcing platforms, discussion forums, open access labs, or multi-financial sourcing system. However, we need to develop new business models where open innovation becomes an integral part of value creation instead of seeking pure financial profit. Industry 4.0, based on smart networks and digitalization connections, requires strong prerequisites for new ways to cooperate. However, we also need mental and moral frameworks for this new mode of cooperation. The ecosystem approach promotes an integrated map, which makes sense when sharing scientific knowledge in real time, within a sustainable development approach, instead of a post-hoc, reactive approach $[9,10]$.

Hence, it is inevitable for all stakeholder groups to closely follow technology and responsible innovation, ensure its integration into education systems, economic systems, natural environments, civil society, and the political system. The system demonstrates societal and scientific importance and highlights its active components: social capital, information capital, economic capital, political capital, and legal capital. These theoretical insights allowed us to construct the methodological basis of the study, justifying the research design, distinguishing the stages of the study: 
(1) Survey research concerning social capital in Poland and Lithuania to access the impact of social capital and trust in stakeholder cooperation;

(2) In-depth interviews with scientists who actively work to transfer knowledge into industry (information and economic capital);

(3) Field note-narratives from working experiences in research management (information capital and politic capital);

(4) Instrumental case analysis of one cluster working with innovation development (economic capital, information capital, politic capital, and legal capital).

Thus, it is important to highlight the main aspects of societal and scientific relevance in order to reinforce the implementation of the responsible innovation approach in industrial ecosystems, focusing on collaboration, technological implementation, and clear benefits of the application. Hence, a properly defined methodological approach is needed to apply this framework, in practice, and to identify the strengths of the relationships between stakeholders. Unfortunately, the present literature examined, e.g., regarding social phenomena, still has some shortcomings. For example, the available studies are mostly at the theoretical level and empirical studies are insufficient. Hence, problems surrounding shared taxonomy and a responsible innovation approach in industrial ecosystem are gaining more relevance; this requires a more detailed analysis, and should be discussed conceptually, and empirically tested.

Conceptualization of responsible research and innovation: the (RRI) concept involves responding to the aforementioned demands for a new mode of cooperation between different stakeholders in the Quadruple Helix model. Among the RRI definitions that exist, we use the approach by the European Commission, regarding the unifying of different viewpoints: " $<\ldots>$ proceeding in research and innovation in ways that allow all stakeholders that are involved in the processes of research and innovation at an early stage (A) to obtain relevant knowledge on the consequences of the outcomes of their actions and on the range of options open to them and (B) to effectively evaluate both outcomes and options in terms of societal needs and moral values and (C) to use these considerations (under A and B) as functional requirements for design and development of new research, products and services. The RRI approach has to be a key part of the research and innovation process and should be established as a collective, inclusive and system-wide approach" [11] (p. 3).

The RRI approach fosters a move from unidirectional push-pull relationships towards rather multi-layered and dynamic interactions, with cooperation among academia, industry, government, and society. When interactions rapidly become more complex, there exists a great diversity of industrial ecosystems [12]. Responding to extremely high complexity, we employed a taxonomy approach. Taxonomic definitions identify the minimum number of properties that are sufficient to demarcate one group of entities from all other entities [13]. Taxonomically ordered relationships between responsibility and innovation are important, because innovations are "challenged" to meet different, potentially conflicting values. For example, according to van de Poel and Sand [14], the safety of the car and modern design creates moral overload. In this sense, responsible innovation means the over-coming of moral overload by innovation, i.e., by developing new options that resolve value conflicts.

In noticing this research gap, we formulated a scientific subject, where universities play an important role in innovation ecosystems by developing human capital and social capital, advancing knowledge to create solutions. Therefore, assuming that science-the university environment is only one of the four elements of the Quadruple Helix model, we decided, with this model, to investigate the impact of the academic environment and science on the business sphere in two CEE countries, i.e., Lithuania and Poland. This conceptual perspective helped us to construct the main research question: $(R Q)$-what kind of relationships exist between science and business in both countries in order to reinforce implementing the responsible innovation approach in industrial ecosystems? How can the results contribute to the development of responsible innovation policy?

The objectives and methods of the present study. The objective of this paper is to identify and evaluate the main aspects of societal and scientific relevance in order to reinforce 
implementation of the responsible innovation approach in industrial ecosystems, focusing on collaboration, technological implementation, and clear benefits of the application. Here, the strength of the relationship between science and business in both countries will be examined and, additionally, the nature of the preferred relationship between the two elements of socioeconomic life will be explored using the interviews. Furthermore, the nature of the relationship between science and business, and the prospects for it, will be explored using interviews with scientists working at universities in Lithuania. Additionally, we integrated field notes from communications with industry experts and a case study "of good practice" in a robotics cluster.

As we previously noted, there is little research/literature on this topic to date. Hence, the research tasks identified above for CEE countries are new, and a research area worth exploring. Our study will reveal whether there is a (fairly) strict local or ecosystem approach to accountability. The authors explored whether there is an approach in this region of Europe (where everyone takes responsibility) for scientists and for industry, or whether there is an ecosystem approach, where a company is seen as a member of a business ecosystem (not as a separate company), with participants who are highly interdependent, and are mainly governed by self-regulatory behavior. However, the question of individual and organizational responsibility remains open and rhetorical. In this context, the positive experiences we discovered through the case study are important. The theoretical contribution of this paper demonstrates a construction of methodology based on the emergent perspective, by adapting the Quadruple Helix model, which emphasized four networks, and new theoretical insights on professional discourse for implementation of the responsible innovation approach in industrial ecosystems. Our research will contribute to sustainability policymaking, providing substantial results to the industrial ecosystem.

The structure of this paper is as follows: the following section will present the literature review, i.e., implementing RRI in science and industry. Section 3 will present the methodology and the research process used in the paper. Section 4 will present the results, and the remaining sections will present the discussion and conclusions.

\section{Conceptual Problems in Implementing RRI in Science and Industry}

A good premise for RRI development is via the phenomenon of science democratization, as the literature indicates [15-17]. A critical attitude of the 'big science' model that evolved after WWII, at the end of 20th century, led to the relevance of giving "more voice" to society. However, as society started to play a more prominent role in science, scholars noticed a growing threat to the freedom of creativity (considered a basic value for scientists). RRI could enable placing different approaches of control and liberty synergetically, regarding processes and outcomes.

Experts note that RRI primarily has limitations in addressing business strategies, especially when the success of a business is measured in financial terms [11]. Therefore, we also need to change the mindsets and strategies in business. Experts argue that companies and individuals who choose to work with the open innovation approach do not experience significant loss in profit or in secret information [18]. Instead, they learn from the experience of failure, which requires more attention [19]. The democratization of science encourages the creation of communities of innovation and information platforms. It is assumed that welfare will be higher in those countries where there are many innovations on various platforms [18].

We can see transformations in the new conceptual models of science, such as "post normal science" and "trans-science" [20]. From our point of view, these transformations encourage scientists to work in organic ways while following the principles of RRI. Nielsen argues that we are living at the dawn of the most dramatic change in science in more than 300 years. This change is driven by powerful new cognitive tools, enabled by the internet. We already have new science models, for example, citizenship science projects, such as Galaxy Zoo, with 200,000 participants, Foldit, which encompasses 75,000 participants, and eBird, with 30 million cases of observations [21]. This corresponds with the research results 
presented in the literature, according to which there is a positive impact of formal education at the academic level on the social competences of students (i.e., future employees). They influence success in professional lives [22].

RRI is a collective responsibility approach. However, the academic code of conduct focuses on universal values, such as truthfulness, and its implementation in science through individual behavior of the researcher. Yet, the idea of how the behavior of each individual scientist becomes part of a joint responsibility is not defined. Furthermore, it should be emphasized that the reflections of scientists, regarding social responsibility, need feedback, and information based on argumentation and analysis, conducted in other scientific areas and practices. They seek to apply their knowledge to solve problems. The main emphasis is placed on individual responsibility of the scientists, which is the core of a team's social responsibility.

Some researchers ponder the following-if responsibility is considered important in science, why have we developed evaluation criteria for scientific excellence, but not for RRI [11]? The European Commission considers that adding certain aspects to already existing regulations could help in developing good practice for RRI. For example, it could be an option to expand RRI categories, e.g., a university's code of conduct. Applicants for EU research funds might be obligated, in their research proposal statements, on how the research might contribute to addressing societal challenges [11]. In recent decades, there has been increased intention of how a higher education system prepares young people for social responsibility [8,23]. In expert opinions, the concept of open science could help implement RRI notions. In 2017, the European Commission released the "Report of the Working Group on Education and Skills under Open Science" [11].

The literature indicates that responsible innovation (RI) "is by definition a normative, values- and purpose-driven concept, which requires the alignment of economic, societal and environmental business goals" [24] (p. 88). According to the literature, companies introducing innovations should not only think about economic goals, i.e., profits, but they should also be responsible towards society, e.g., by developing direct relations with local communities or consumers. Moreover, the main drivers of responsible innovation include internal drivers, namely moral standards of high-level decision-makers within firms, external drivers, e.g., ethical and belief systems prevalent in specific regions, communities, and/or countries, legal frameworks, public funding programs, relational drivers, namely stakeholder relations, and public relations [24] (p. 89). Similarly, Martinuzzi et al. [25] argue that the responsibility of industry towards society means that companies implementing innovations should not only improve their competitiveness, but should also strive "to maintain public trust in industry through innovations that generate social value in addition to economic returns" [24] (p. 1). Thus, it is the task of the enterprise to adapt the innovation to the external environment and to the relationships in which the economic actor engages [26]. Here, the role of social capital is revealed. According to Mazzucchelli et al. [27], structural social capital plays a critical role in enhancing knowledge exchange and innovation capabilities. Social capital facilitates the entrepreneurial process, especially in large entities, including international multi-site franchises [28]. If people working with each other trust each other, then they are more likely to cooperate and give each other (or even other teams) useful advice [29]. Trust increases the possibilities of knowledge exchange within the enterprise [30], which promotes innovation. Moreover, if relational social capital emerges in enterprises, it also facilitates the internationalization process of small- and medium-sized enterprises [31]. Moreover, social capital has a nationwide influence on entrepreneurship. As Argentiero et al. [32] notes, economic growth models with social capital, and social capital combined with human capital, fit the actual pattern of "total factor productivity" better. Social capital supports a better allocation of resources, economic activity, and the impact of innovation on the economy. This therefore points to a nationwide beneficial impact of social capital, innovation, and a relationship between social capital and innovation implementation and accountability. 
As the literature indicates, social capital includes not only relationships and trust, social competence, and a link to academic education, but also institutional relationships and public perceptions of the state [33]. Such multi-directional relationships found in social capital theory are in line with the RRI concept, which emphasizes the need for cooperation between stakeholders, such as the state, academia (science), industry, and society. This is needed because companies are often unaware of the negative consequences of inappropriate innovation implementation [34]. To prevent the negative effects of irresponsible innovation, the European Commission introduced a framework for responsible research and innovation (RRI) [35]. In this framework, implementing RRI requires multiple stakeholders to work together to find solutions to societal challenges. It emphasizes the need for innovators, businesses, social actors, research funders, and policymakers to work together [36]. This need exists because a company implementing innovations is a member of a business ecosystem with participants who are highly interdependent on each other and governed by self-regulatory behavior. It may also be that the environment in which innovations are implemented may be regulated, which entails the need for collaboration with multiple government institutions [35]. Hence, when analyzing the concept of responsible research and innovation, attention should also be placed on factors such as the public's perception of democracy, the level of civil society, and the evaluation of the general activity of public institutions. Following the definition of the state by G. Jellinek [37], the literature indicates that social capital analysis can be useful to analyze this type of relationship, especially the perception of the state [33].

In this article, by identifying the fundamental conceptual problems in the RRI field and discussing contradictions among all stakeholder groups, and combining different theoretical paradigms in practice, we show a unified picture platform to highlight the uniformity of all components (scientific institutions-researchers; economics-industry; governance-policy-forming; society-citizens). We show the level of freedom of activity, the level of responsibility, and the values in industrial ecosystems.

We also address the elimination of the separation of the theory and practice of RRI implementation. In this way, we show that implementing RRI could assist all stakeholder groups in following technology and responsible innovation closely, ensuring its integration into the education system, economic system, natural environment, civil society, and the political system, and synergy in the RRI processes and outcomes. We investigate the link between RRI in theory and RRI in practice, having demonstrated the beneficial impacts of social capital.

\section{Research Design: RRI as a New Narrative-A Mixed Research Strategy}

RRI is a new narrative that should support the ecosystem of science and industry. That is why it is important to recognize it and to ensure it is not overshadowed. Since the middle of the 20th century, science has been dominated by so-called grand narratives [38,39]. Nowadays, we are expected to recognize the importance of a different, so-called small narrative that recognizes and validates a multitude of voices within a society, which is not heard by the "grand narrative" for various reasons [39]. A narrative is "the main mode of knowing and communicating in organizations' $[40,41]$. Narratives are very helpful when dealing with tacit knowledge or communicating technological impacts [42]. New points of view towards narratives enable understanding of spontaneous storytelling episodes in interviews. As for small narratives-“"storytelling in contemporary organizations hardly follows the traditional pattern of a narrator telling a story from the beginning to the end in front of an enchanted and attentive audience" [40] (p. 60).

Following the Emergent perspective, a mixed research strategy, and an instrumental case study design was employed as the most suitable methodology to achieve answers to the main research question raised in this study. This design enabled us to develop certain theoretical insights and to test empirically. The research adopted the case study design in order to understand the phenomena at hand. Our paper uses the Quadruple Helix model [43] to explore the strength of the relationships between social society, government, 
industry (business), and academia, represented by universities (academic actors) (Figure 1). This will allow us to assess the strength of the relationships between the different actors of the innovation ecosystem and, thus, determine the statistical significance of these relationships, e.g., between universities and business, to identify whether or not these relationships are well developed in the countries studied. We adapted this theoretical concept for our own case study. As Bellandi et al. [44] notes, partnerships of such actors can foster social innovation and support the social commitment of each actor.

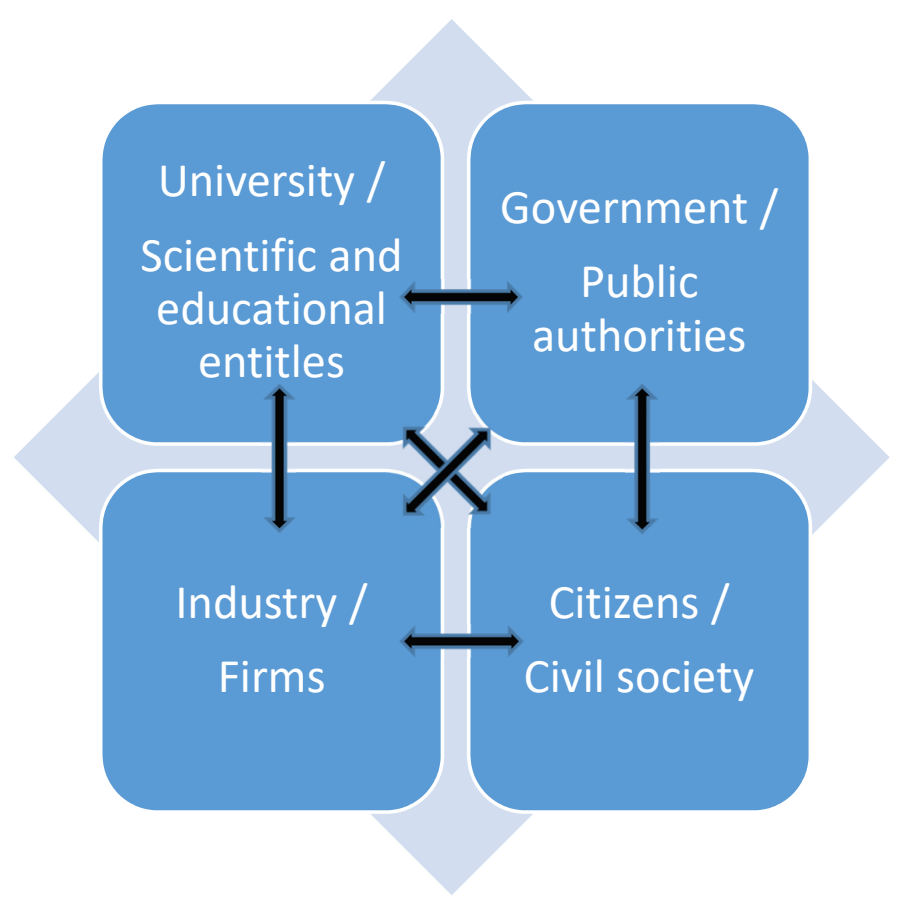

Figure 1. Relationships in the innovation ecosystem among actors, according to the Quadruple Helix model.

First, we started with a quantitative research data collection method. We carried out the survey on social capital, in terms of trust, attitudes towards democracy, civil society, and community involvement, attitudes towards authorities at different levels, and their activities, towards businesses, different professions, and the academic community. It was used to explore the relationship between these four actors, including between science and business (which is the most important one from the point of view of the aim of this paper). The survey consisted of 10 survey questions about social capital (the content of the questions used is presented later) and questions presenting the characteristics of the respondents. The questions on social capital were developed according to a logical model proposed by the World Bank [45]. For the survey questions, a 5-point Likert scale was used, where, depending on the question, the possible answers ranged from 1-I don't trust to 5-I trust very much, or 1-Very bad to 5-Very good or 1-Definitely not to 5-Definitely yes. Surveys were conducted in late 2019 and early 2020 (XII.2019-I.2020) in Poland and Lithuania. Recruitment of respondents was carried out in the form of an announcement inviting participants to the study, placed on notice boards at university buildings in both countries. It was possible to fill out the questionnaire in paper form or online. In the random and anonymous questionnaire, respondents were surveyed in regards to continuing their education and their contacts with businesses (i.e., either via work or cooperating with a business). A total of 148 respondents were surveyed in Poland and 68 in Lithuania. Table 1 presents the characteristics of the respondents. 
Table 1. Characteristics of research samples.

\begin{tabular}{cccc}
\hline & Itemization & Poland & Lithuania \\
\hline \multirow{2}{*}{ Gender (share in \%) } & women & 68.2 & 73.5 \\
\cline { 2 - 4 } & men & 31.8 & 26.5 \\
\cline { 2 - 4 } Age (share in \%) & up to 20 & 25.0 & 19.1 \\
\cline { 2 - 4 } & $21-24$ & 60.8 & 66.2 \\
\cline { 2 - 4 } & 25 and more & 14.2 & 14.7 \\
\cline { 2 - 4 } Professional situation (share in \%) & working full time & 4.1 & 26.0 \\
\cline { 2 - 4 } & part-time workers & 33.8 & 19.2 \\
\cline { 2 - 4 } & own business & 25.7 & 12.3 \\
\cline { 2 - 4 } & $\begin{array}{c}\text { unemployed or temporarily out } \\
\text { of business }\end{array}$ & 36.5 & 35.6 \\
\hline
\end{tabular}

In both research groups, the majority were women, with a predominance of 21-24-yearolds, although there was also a significant proportion (14-15\%) of older people. This age distribution was due to the age range at which students typically enter higher education. Of the respondents, most were full-time or part-time workers.

This research analyzed how the respondents rated social commitment and trust (which, in a way, also promotes social innovation) of each of the four 'Quadruple Helix' stakeholders (see Figure 1). For each entity, two questions were selected; in each of them, the assessment took place according to a 5-point Likert scale.

Government, and on its behalf the administration and public institutions, through their activities can support innovation, including social innovation, and promote dialogue with the citizens. However, a positive assessment of these institutions and trust in them is necessary here. For this reason, two survey questions were used in the study: How do you recognize the attitude towards the activity of public institutions (government) at the central level (G1)? To what extent do you think officials (employees) of public institutions are honest (G2)? The second stakeholder in the Quadruple Helix model involves civil society. It is for them that innovations are created by companies. Democracy should enable citizens to co-decide on issues that affect them, and not just require citizens to be passive recipients of what is happening. Hence, it is essential for citizens to feel that their decisions and actions have an impact on the reality in which they live. Therefore, in relation to the analysis of this subject, the authors used the questions regarding whether respondents agreed with the statement that their voices mattered (CS1) and that their actions and decisions had an impact on other people and the local environment (CS2). The third helix, the stakeholder, involves companies. Firms should support innovations that will develop industry, but also serve society, not just exploit it. The following two questions were therefore used for the assessment: do you agree with the statement that it is our duty to help others, people who are poor, sick, or in a difficult life situation (F1)? Do you agree that volunteers are free labor (F2)? The fourth entity is science, represented by universities. Since science and business should cooperate with each other, it is important to remember the assumption made by the authors that universities play an important role in innovation ecosystems by developing human and social capital and transferring knowledge for solutions. Universities, after all, create pro-innovation activity by the societies they educate and support other actors in implementing innovations. However, for this to be possible, we need to trust academics and have confidence in their honesty and integrity. Therefore, the following two survey questions were used for the evaluation: how much trust do you have in the university's research and teaching Staff (U1)? To what extent do you think university staff are honest (U2)?

Since the purpose of this article is to investigate the influence of academia and science on the business sphere, the next step in the methodological process was to examine the 
dependence and strength of the relationships among the four elements in the quadruple helix model. The use of statistical methods is necessary to calculate the strength and direction of the relationship between stakeholders of the innovation ecosystem (in the Quadruple Helix model). This is important in order to assess whether such relationships exist and between which stakeholders. Importantly, by using statistical methods, it will be possible to assess whether these relationships are statistically significant. As the subject of analysis in this article involves the relationship between the university sector and business, it is possible to assess whether these relationships differ from the relationships between other stakeholders. Assessing the two questions provides an opportunity to determine in which areas possible relationships occur. The Chi-square independence test with a significance level of 0.05 was used to examine the dependence, while the Cramer's V test was used to examine the strength of the dependence. These particular tests were used because we are dealing with qualitative variables, with a 5-point Likert scale. Thus, the results obtained will be objective measurements, not just subjective, of the existing (or lack of existing) relationships. These tests will assess whether a relationship exists and the strength of this relationship among the entities in the Quadruple Helix model used, including the relationship between universities and companies.

Then, a qualitative research strategy with interviews was used. The second research study conducted for this article was an interview to discover the characteristics of the relationship between science and business, and the challenges between them. There were four participants who were leaders-experts in their scientific fields at the universityone female and three males, with an age range of 40 to 55 years old. Participants were collected purposely, as the objective was to have a productive conversation. In this case, data were collected from multiple sources. First, from four in-depth interviews with leading researchers in the field of technology-academic researchers who had close links to industry and business. Second, field note data from daily working conversations and casual discussions with colleagues were integrated in order to establish fact-based solutions and to answer the proposed research question In accordance with the ethical standards, the research anonymized the names of the participants; they are not personally identified, but instead codified as (I) informants. The authors emphasized that the main dimension of the interview focused on the areas of the relationship between science and business in order to reinforce the implementation of the responsible innovation approach in industrial ecosystems. Based on this dimension, the interview was constructed by drawing two main scenarios (to address the main research question): (1) the expression of the RRI processes taking place in the universities and industry; (2) the reflections, how the results achieved in industrial ecosystems contribute to the development of the responsible innovation policy. During the in-depth interviews, the informants were invited to discuss their stories regarding how their experiences in implementing RRI, and their roles, activities, and issues in this initiative. Each interview lasted for 2-3.5 h. However, all participants could join, fill in their thoughts, and continue the stories/narratives at any time. Upon listening to the informant narratives, three themes became apparent: subjectification of ethics, the need for new governance of research, and new establishments.

Third, good instrumental case study practices was analyzed. We analyzed one advanced robotics cluster in Lithuania, which creates innovations and innovative products across the Baltic region.

Several research methods were used within this study. We focused on thematic analysis, with the aim of describing the implementation of RRI in an industrial ecosystem, to obtain full reflections and comments, and understand how each stakeholder group could be involved during the entire process. Furthermore, based on field notes, we wove together our own (and other) stories by "following the utterances of others as well as making utterances that allow others to follow" [46] (p. 109). The information obtained by various methods allowed us to triangulate the data. 


\section{Research Findings: Challenging the Social Practice of Implementing RRI in Science and Industry}

As a first step, an examination of the relationships between the ecosystem actors was undertaken. In this case, quantitative analysis methods were used. First, they were used to evaluate the results from the surveys for each ecosystem actor, and then relationship analysis methods were used to evaluate the relationships between each stakeholder. For this reason, each stakeholder in the Quadruple Helix model was first assessed using surveys. The first actor assessed by the respondents was the government.

The results show (Figure 2 left panel) that the government, the public sector, and its activity, is generally negatively assessed by society, i.e., there are more negative judgments (very bad or bad) than positive ones (very good or good). This assessment is because respondents believe the government takes little action for the benefit of society or for the common good, i.e., other members of the ecosystem. There are more people in Poland (over $50 \%$ ) than in Lithuania (over 1/3), who negatively assessed government activity. Moreover, respondents believe (Figure 2 right panel) that officials in public institutions are either rather dishonest or very dishonest. This is a sad conclusion; such an attitude will certainly not encourage businesses, universities, or society to cooperate with the government in implementing innovations.
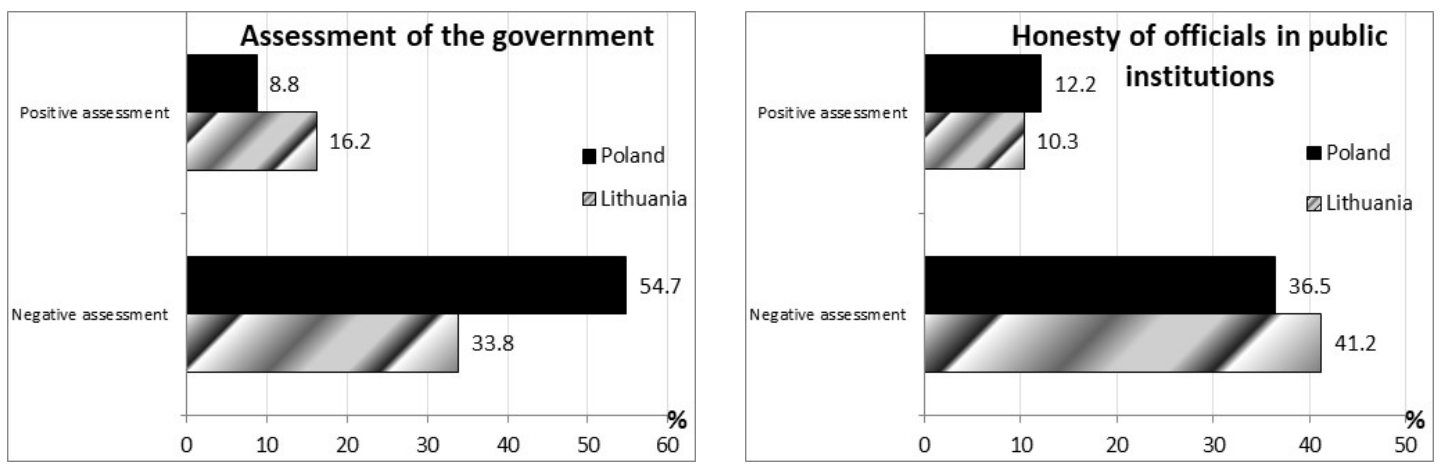

Figure 2. Assessment of the government at the central level (left panel) and the honesty of officials in public institutions (right panel).

Another ecosystem actor analyzed was society, understood as civil society. It was analyzed in the context that society could "co-determine" and not just be a passive recipient. Therefore, we examined whether the respondents believed that their voices matter and whether their actions and decisions have an impact on other people and the local environment (Figure 3).

The results indicated that most of the respondents feel that they can co-determine the issues that affect them, i.e., their voice matters. Moreover, they feel that their decisions and actions have an impact on the reality in which they live. This is an important conclusion, since innovations are created for them by companies. It is also worth mentioning that a higher percentage of respondents with a positive attitude to this issue were in Lithuania (about $70 \%$ ) than in Poland (51-57\%).

The third entity considered in the Quadruple Helix model and analyzed were companies. As companies implement innovations, they should ideally be innovations that serve society. At the same time companies, should not treat their partners, especially universities, as cheap labor forces; therefore, we investigated if the respondents (employees and company owners) agreed with the statement that it was their duty to help others, people who are poor, sick, or in a difficult life situation. Furthermore, we investigated whether companies consider volunteers as free labor. The results of this analysis are presented in Figure 4. 


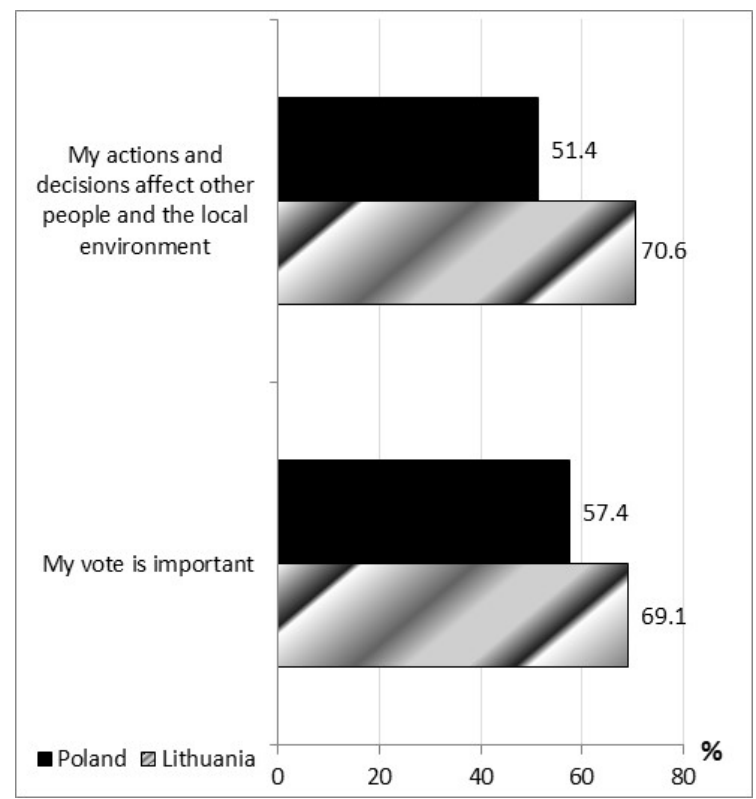

Figure 3. Percentage of respondents who agree with specific statements about the impact of their vote on the democratic system or their actions on other people and the local environment.

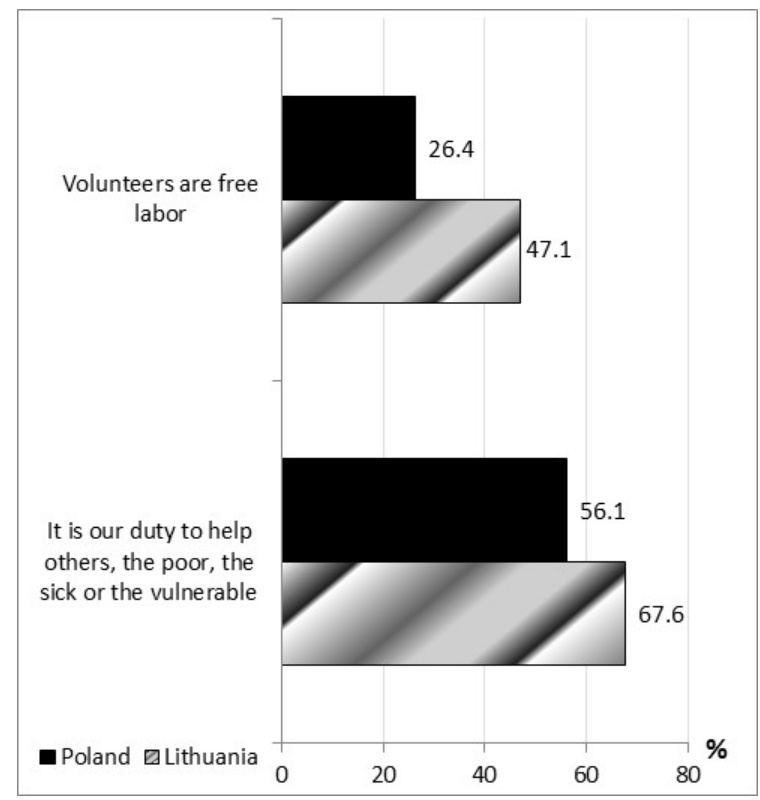

Figure 4. Percentage of respondents who agree with specific statements about company treatment of volunteers and support for society.

The results showed that less than half of the respondents believe that volunteers are free labor for business. It should be noted that, while in Poland, just over $1 / 4$ of respondents believe so, in Lithuania, as much as $47 \%$ have such an opinion. Fortunately, positive conclusions arise from the results for the second question, i.e., the need to help others. The results showed that $56.1 \%$ of respondents in Poland and $67.6 \%$ in Lithuania answered this question in the affirmative. This means that, in their declarations, companies may be willing to consider pro-social interests in their decisions, including innovation decisions.

The last stakeholder analyzed was the universities and the academics working there. Since science and business should cooperate with each other, there must be trust in academics, as well as honesty and reliability. Figure 5 shows the results of answers to the 
question - how much trust do you have in the university's research and teaching staff (left panel) and to what extent do you think the university staff is honest (right panel)?
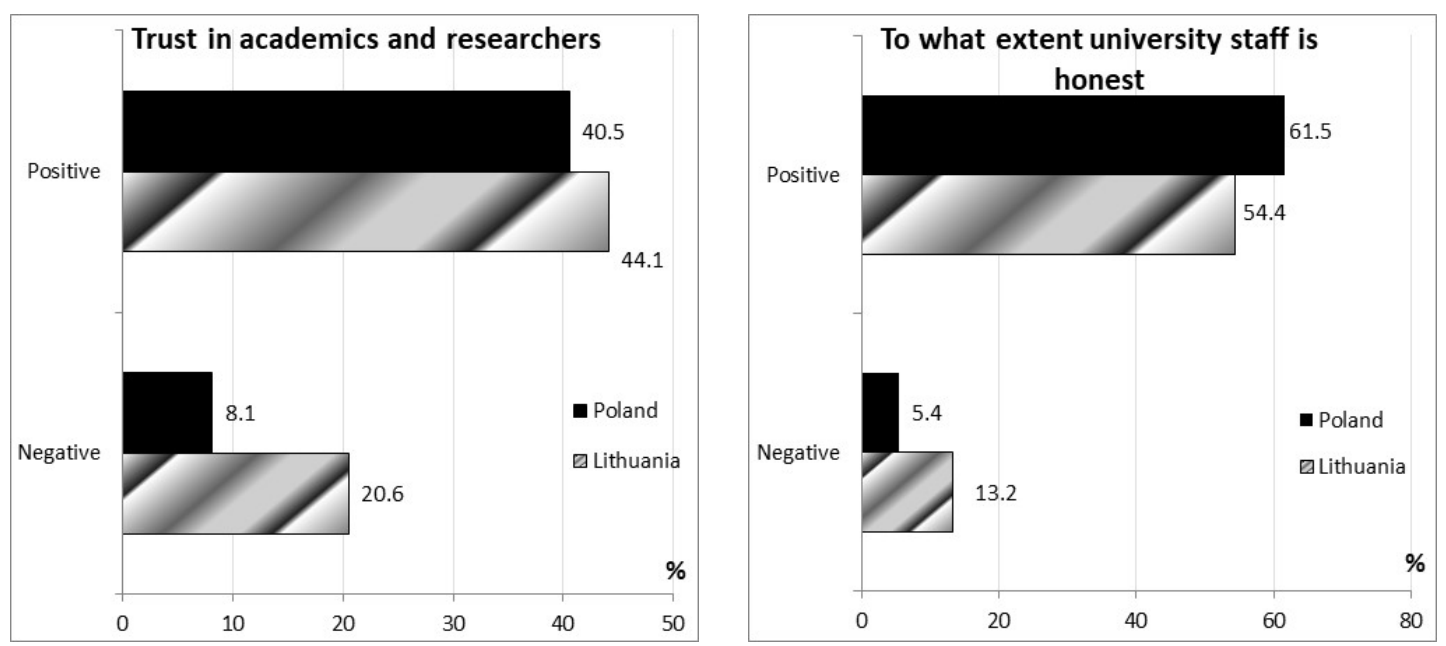

Figure 5. Respondent evaluations of universities and academics.

The results indicate that, in both studied countries, more people trust than distrust university staff; however, just over $40 \%$ of respondents have such trust, which means that the same number of people do not have an opinion on this aspect. On the positive side, more than half of the respondents believe that the university staff are honest.

Having made a preliminary assessment of each of the actors in the innovation ecosystem, the authors of this paper then proceeded to examine whether there are relationships among government, society, companies (business), and universities, and what the strengths of these relationships are. This will allow one to assess the relationships between helix actors. As we are interested in the relations between science and business, by examining the relations for all stakeholders, it was possible to compare them. The results from assessing the relationships using the Chi-square test of independence, and the strengths of the relationships using Cramer's V test, are presented in Table 2.

The results for Poland showed that there is a statistically significant (at $p<0.05)$ relationship between some of the ecosystem actors, in terms of cooperation with a social dimension. As far as the government is concerned, such a relationship exists in terms of cooperation with society and business. The relationship is strong, especially in terms of government activity and citizens feeling that their voices matter. This indicates that if the government undertakes any actions involving the society, the society feels positive about this activity. As far as companies are concerned, there is a correlation between trust in government officials and the inclination of companies to help others, the society. This means that if companies know that the public administration is honest, then companies are more willing to engage in pro-social activities and social innovation. With regard to companies, the survey results also indicate their interdependence with society. In this case, it concerns all aspects of pro-social interdependence. When people are willing to engage in community and voluntary work, then companies are willing to engage in innovation and social work. This also works the other way round, i.e., when society perceives that companies engage in such activities, then society feels that their activities make sense. However, when analyzed from the perspective of universities, science, the results indicated that there is no statistically significant relationship with any of the actors in Poland (government, society, companies). It should be noted, however, that with $92 \%$ probability, it could be concluded that if one trusts that the university staff is honest, then society believes it makes them "active", and it can have a positive impact on other people and the local environment. No statistically significant relationship was found among trust in universities/scientists and pro-social activities or innovations undertaken by companies. 
The results showed (Table 3) that similar conclusions on the dependencies between actors are found in Lithuania, although in this country, these relationships are found to a slightly lesser extent. There is a very strong relationship between the government and universities, more specifically, trust in public officials and belief in the integrity of academics. Moreover, a relationship among companies and society, and universities and society, was found in the same areas as for Poland. Similarly, here it was found that there is no statistically significant relationship between companies and universities in Lithuania.

Table 2. Statistics for Chi-square test of independence and Cramer's V test for Poland.

\begin{tabular}{|c|c|c|c|c|c|c|c|c|c|}
\hline \multicolumn{2}{|c|}{ Entity/Question } & G1 & G2 & CS1 & CS2 & F1 & F2 & U1 & U2 \\
\hline \multirow[t]{2}{*}{ Government } & G1 & n.a. & n.a. & $\begin{array}{c}\text { Chi-sq. }= \\
31.75 \\
p=0.0108 \\
\mathrm{~V}=0.2316\end{array}$ & $\begin{array}{c}\text { Chi-sq. }= \\
25.23 \\
p=0.0659 \\
\mathrm{~V}=0.2064\end{array}$ & $\begin{array}{c}\text { Chi-sq. }= \\
17.90 \\
p=0.3296 \\
\mathrm{~V}=0.1739\end{array}$ & $\begin{array}{c}\text { Chi-sq. }= \\
22.15 \\
p=0.1384 \\
\mathrm{~V}=0.1934\end{array}$ & $\begin{array}{c}\text { Chi-sq. }= \\
18.75 \\
p=0.2819 \\
\mathrm{~V}=0.1780\end{array}$ & $\begin{array}{c}\text { Chi-sq. }= \\
19.65 \\
p=0.2364 \\
\mathrm{~V}=0.1822\end{array}$ \\
\hline & $\mathrm{G} 2$ & n.a. & n.a. & $\begin{array}{c}\text { Chi-sq. }= \\
23.32 \\
p=0.0251 \\
\mathrm{~V}=0.2292\end{array}$ & $\begin{array}{c}\text { Chi-sq. }= \\
20.57 \\
p=0.0570 \\
\mathrm{~V}=0.2153\end{array}$ & $\begin{array}{c}\text { Chi-sq. }= \\
26.83 \\
p=0.0082 \\
\mathrm{~V}=0.2458\end{array}$ & $\begin{array}{c}\text { Chi-sq. }= \\
12.02 \\
p=0.4437 \\
\mathrm{~V}=0.1646\end{array}$ & $\begin{array}{c}\text { Chi-sq. }= \\
15.89 \\
p=0.1963 \\
\mathrm{~V}=0.1892\end{array}$ & $\begin{array}{c}\text { Chi-sq. }= \\
13.25 \\
p=0.3514 \\
\mathrm{~V}=0.1727\end{array}$ \\
\hline \multirow[t]{2}{*}{$\begin{array}{c}\text { Civil } \\
\text { society }\end{array}$} & CS1 & $\begin{array}{c}\text { Chi-sq. }= \\
31.75 \\
p=0.0108 \\
\mathrm{~V}=0.2316\end{array}$ & $\begin{array}{c}\text { Chi-sq. }= \\
23.32 \\
p=0.0251 \\
\mathrm{~V}=0.2292\end{array}$ & n.a. & n.a. & $\begin{array}{c}\text { Chi-sq. }= \\
32.29 \\
p=0.0092 \\
\mathrm{~V}=0.2335\end{array}$ & $\begin{array}{c}\text { Chi-sq. }= \\
32.55 \\
p=0.0085 \\
\mathrm{~V}=0.2345\end{array}$ & $\begin{array}{c}\text { Chi-sq. }= \\
11.92 \\
p=0.7496 \\
\mathrm{~V}=0.1419\end{array}$ & $\begin{array}{c}\text { Chi-sq. }= \\
15.73 \\
p=0.4719 \\
\mathrm{~V}=0.1630\end{array}$ \\
\hline & $\mathrm{CS} 2$ & $\begin{array}{c}\text { Chi-sq. }= \\
25.23 \\
p=0.0659 \\
\mathrm{~V}=0.2064\end{array}$ & $\begin{array}{c}\text { Chi-sq. }= \\
20.57 \\
p=0.0570 \\
V=0.2153\end{array}$ & n.a. & n.a. & $\begin{array}{c}\text { Chi-sq. }= \\
26.35 \\
p=0.0493 \\
\mathrm{~V}=0.2110\end{array}$ & $\begin{array}{c}\text { Chi-sq. }= \\
28.77 \\
p=0.0256 \\
\mathrm{~V}=0.2204\end{array}$ & $\begin{array}{c}\text { Chi-sq. }= \\
15.20 \\
p=0.5098 \\
\mathrm{~V}=0.1603\end{array}$ & $\begin{array}{c}\text { Chi-sq. }= \\
24.58 \\
p=0.0777 \\
\mathrm{~V}=0.2037\end{array}$ \\
\hline \multirow[t]{2}{*}{ Firms } & $\mathrm{F} 1$ & $\begin{array}{c}\text { Chi-sq. }= \\
17.90 \\
p=0.3296 \\
\mathrm{~V}=0.1739\end{array}$ & $\begin{array}{c}\text { Chi-sq. }= \\
26.83 \\
p=0.0082 \\
\mathrm{~V}=0.2458\end{array}$ & $\begin{array}{c}\text { Chi-sq. }= \\
32.29 \\
p=0.0092 \\
\mathrm{~V}=0.2335\end{array}$ & $\begin{array}{c}\text { Chi-sq. }= \\
26.35 \\
p=0.0493 \\
\mathrm{~V}=0.2110\end{array}$ & n.a. & n.a. & $\begin{array}{c}\text { Chi-sq. }= \\
10.99 \\
p=0.8102 \\
\mathrm{~V}=0.1362\end{array}$ & $\begin{array}{c}\text { Chi-sq. }= \\
16.49 \\
p=0.4194 \\
\mathrm{~V}=0.1669\end{array}$ \\
\hline & $\mathrm{F} 2$ & $\begin{array}{c}\text { Chi-sq. }= \\
22.15 \\
p=0.1384 \\
\mathrm{~V}=0.1934\end{array}$ & $\begin{array}{c}\text { Chi-sq. }= \\
12.02 \\
p=0.4437 \\
\mathrm{~V}=0.1646\end{array}$ & $\begin{array}{c}\text { Chi-sq. }= \\
32.55 \\
p=0.0085 \\
\mathrm{~V}=0.2345\end{array}$ & $\begin{array}{c}\text { Chi-sq. }= \\
28.77 \\
p=0.0256 \\
\mathrm{~V}=0.2204\end{array}$ & n.a. & n.a. & $\begin{array}{c}\text { Chi-sq. }= \\
17.42 \\
p=0.3595 \\
\mathrm{~V}=0.1715\end{array}$ & $\begin{array}{c}\text { Chi-sq. }= \\
20.72 \\
p=0.1896 \\
\mathrm{~V}=0.1871\end{array}$ \\
\hline \multirow[t]{2}{*}{ University } & U1 & $\begin{array}{c}\text { Chi-sq. }= \\
18.75 \\
p=0.2819 \\
\mathrm{~V}=0.1780\end{array}$ & $\begin{array}{c}\text { Chi-sq. }= \\
15.89 \\
p=0.1963 \\
\mathrm{~V}=0.1892\end{array}$ & $\begin{array}{c}\text { Chi-sq. }= \\
11.92 \\
p=0.7496 \\
\mathrm{~V}=0.1419\end{array}$ & $\begin{array}{c}\text { Chi-sq. }= \\
15.20 \\
p=0.5098 \\
\mathrm{~V}=0.1603\end{array}$ & $\begin{array}{c}\text { Chi-sq. }= \\
10.99 \\
p=0.8102 \\
\mathrm{~V}=0.1362\end{array}$ & $\begin{array}{c}\text { Chi-sq. }= \\
17.42 \\
p=0.3595 \\
\mathrm{~V}=0.1715\end{array}$ & n.a. & n.a. \\
\hline & $\mathrm{U} 2$ & $\begin{array}{c}\text { Chi-sq. }= \\
19.65 \\
p=0.2364 \\
\mathrm{~V}=0.1822\end{array}$ & $\begin{array}{c}\text { Chi-sq. }= \\
13.25 \\
p=0.3514 \\
\mathrm{~V}=0.1727\end{array}$ & $\begin{array}{c}\text { Chi-sq. }= \\
15.73 \\
p=0.4719 \\
\mathrm{~V}=0.1630\end{array}$ & $\begin{array}{c}\text { Chi-sq. }= \\
24.58 \\
p=0.0777 \\
\mathrm{~V}=0.2037\end{array}$ & $\begin{array}{c}\text { Chi-sq. }= \\
16.49 \\
p=0.4194 \\
\mathrm{~V}=0.1669\end{array}$ & $\begin{array}{c}\text { Chi-sq. }= \\
20.72 \\
p=0.1896 \\
\mathrm{~V}=0.1871\end{array}$ & n.a. & n.a. \\
\hline
\end{tabular}

Abbreviations used in the table: Chi-sq.—Chi-square test value; $p \multimap p$ value; V—Cramer's V test value.

Table 3. Statistics for Chi-square test of independence and Cramer's V test for Lithuania.

\begin{tabular}{|c|c|c|c|c|c|c|c|c|c|}
\hline Entity/Q & tion & G1 & G2 & CS1 & CS2 & F1 & F2 & U1 & $\mathrm{U} 2$ \\
\hline \multirow[t]{2}{*}{ Government } & G1 & n.a. & n.a. & $\begin{array}{c}\text { Chi-sq. }= \\
19.06 \\
p=0.2654 \\
\mathrm{~V}=0.2647\end{array}$ & $\begin{array}{c}\text { Chi-sq. }= \\
13.11 \\
p=0.3612 \\
\mathrm{~V}=0.2535\end{array}$ & $\begin{array}{c}\text { Chi-sq. }= \\
13.79 \\
p=0.3144 \\
\mathrm{~V}=0.2600\end{array}$ & $\begin{array}{c}\text { Chi-sq. }= \\
21.25 \\
p=0.1692 \\
\mathrm{~V}=0.2795\end{array}$ & $\begin{array}{c}\text { Chi-sq. }= \\
16.33 \\
p=0.4304 \\
\mathrm{~V}=0.2450\end{array}$ & $\begin{array}{c}\text { Chi-sq. }= \\
22.18 \\
p=0.1374 \\
\mathrm{~V}=0.2856\end{array}$ \\
\hline & G2 & n.a. & n.a. & $\begin{array}{c}\text { Chi-sq. }= \\
18.02 \\
p=0.1150 \\
\mathrm{~V}=0.2972\end{array}$ & $\begin{array}{c}\text { Chi-sq. }= \\
13.57 \\
p=0.1385 \\
\mathrm{~V}=0.2579\end{array}$ & $\begin{array}{c}\text { Chi-sq. }= \\
7.69 \\
p=0.5654 \\
\mathrm{~V}=0.1942\end{array}$ & $\begin{array}{c}\text { Chi-sq. }= \\
9.35 \\
p=0.6730 \\
\mathrm{~V}=0.2141\end{array}$ & $\begin{array}{c}\text { Chi-sq. }= \\
13.06 \\
p=0.3644 \\
\mathrm{~V}=0.2531\end{array}$ & $\begin{array}{c}\text { Chi-sq. }= \\
80.71 \\
p=0.0000 \\
\mathrm{~V}=0.6290\end{array}$ \\
\hline \multirow[t]{2}{*}{$\begin{array}{c}\text { Civil } \\
\text { society }\end{array}$} & CS1 & $\begin{array}{c}\text { Chi-sq. }= \\
19.06 \\
p=0.2654 \\
\mathrm{~V}=0.2647\end{array}$ & $\begin{array}{c}\text { Chi-sq. }= \\
18.02 \\
p=0.1150 \\
\mathrm{~V}=0.2972\end{array}$ & n.a. & n.a. & $\begin{array}{c}\text { Chi-sq. }= \\
16.30 \\
p=0.1780 \\
\mathrm{~V}=0.2826\end{array}$ & $\begin{array}{c}\text { Chi-sq. }= \\
22.22 \\
p=0.1363 \\
\mathrm{~V}=0.2858\end{array}$ & $\begin{array}{c}\text { Chi-sq. }= \\
7.71 \\
p=0.9571 \\
\mathrm{~V}=0.1683\end{array}$ & $\begin{array}{c}\text { Chi-sq. }= \\
12.68 \\
p=0.6959 \\
\mathrm{~V}=0.2159\end{array}$ \\
\hline & CS2 & $\begin{array}{c}\text { Chi-sq. }= \\
13.11 \\
p=0.3612 \\
\mathrm{~V}=0.2535\end{array}$ & $\begin{array}{c}\text { Chi-sq. }= \\
13.57 \\
p=0.1385 \\
\mathrm{~V}=0.2579\end{array}$ & n.a. & n.a. & $\begin{array}{c}\text { Chi-sq. }= \\
13.29 \\
p=0.1500 \\
\mathrm{~V}=0.2552\end{array}$ & $\begin{array}{c}\text { Chi-sq. }= \\
27.05 \\
p=0.0076 \\
\mathrm{~V}=0.3641\end{array}$ & $\begin{array}{c}\text { Chi-sq. }= \\
9.46 \\
p=0.6632 \\
\mathrm{~V}=0.2153\end{array}$ & $\begin{array}{c}\text { Chi-sq. }= \\
20.20 \\
p=0.0633 \\
V=0.3147\end{array}$ \\
\hline
\end{tabular}


Table 3. Cont

\begin{tabular}{|c|c|c|c|c|c|c|c|c|c|}
\hline \multicolumn{2}{|c|}{ Entity/Question } & \multirow{2}{*}{$\begin{array}{c}\text { G1 } \\
\text { Chi-sq. }= \\
13.79 \\
p=0.3144 \\
\mathrm{~V}=0.2600\end{array}$} & \multirow{2}{*}{$\begin{array}{c}\text { G2 } \\
\text { Chi-sq. }= \\
7.69 \\
p=0.5654 \\
\mathrm{~V}=0.1942\end{array}$} & \multirow{2}{*}{$\begin{array}{c}\text { CS1 } \\
\text { Chi-sq. }= \\
16.30 \\
p=0.1780 \\
\mathrm{~V}=0.2826\end{array}$} & \multirow{2}{*}{$\begin{array}{c}\text { CS2 } \\
\text { Chi-sq. }= \\
13.29 \\
p=0.1500 \\
\mathrm{~V}=0.2552\end{array}$} & \multirow{2}{*}{$\begin{array}{l}\text { F1 } \\
\text { n.a. }\end{array}$} & \multirow{2}{*}{$\begin{array}{l}\text { F2 } \\
\text { n.a. }\end{array}$} & \multirow{2}{*}{$\begin{array}{c}\mathbf{U 1} \\
\text { Chi-sq. }= \\
9.85 \\
p=0.6288 \\
\mathrm{~V}=0.2198\end{array}$} & \multirow{2}{*}{$\begin{array}{c}\mathbf{U} 2 \\
\text { Chi-sq. }= \\
16.28 \\
p=0.1786 \\
\mathrm{~V}=0.2825\end{array}$} \\
\hline Firms & $\mathrm{F} 1$ & & & & & & & & \\
\hline & $\mathrm{F} 2$ & $\begin{array}{c}\text { Chi-sq. }= \\
21.25 \\
p=0.1692 \\
\mathrm{~V}=0.2795\end{array}$ & $\begin{array}{c}\text { Chi-sq. }= \\
9.35 \\
p=0.6730 \\
\mathrm{~V}=0.2141\end{array}$ & $\begin{array}{c}\text { Chi-sq. }= \\
22.22 \\
p=0.1363 \\
\mathrm{~V}=0.2858\end{array}$ & $\begin{array}{c}\text { Chi-sq. }= \\
27.05 \\
p=0.0076 \\
\mathrm{~V}=0.3641\end{array}$ & n.a. & n.a. & $\begin{array}{c}\text { Chi-sq. }= \\
14.57 \\
p=0.5565 \\
\mathrm{~V}=0.2314\end{array}$ & $\begin{array}{c}\text { Chi-sq. }= \\
16.37 \\
p=0.4271 \\
V=0.2454\end{array}$ \\
\hline \multirow[t]{2}{*}{ University } & U1 & $\begin{array}{c}\text { Chi-sq. }= \\
16.33 \\
p=0.4304 \\
\mathrm{~V}=0.2450\end{array}$ & $\begin{array}{c}\text { Chi-sq. }= \\
13.06 \\
p=0.3644 \\
\mathrm{~V}=0.2531\end{array}$ & $\begin{array}{c}\text { Chi-sq. }= \\
7.71 \\
p=0.9571 \\
\mathrm{~V}=0.1683\end{array}$ & $\begin{array}{c}\text { Chi-sq. }= \\
9.46 \\
p=0.6632 \\
\mathrm{~V}=0.2153\end{array}$ & $\begin{array}{c}\text { Chi-sq. }= \\
9.85 \\
p=0.6288 \\
\mathrm{~V}=0.2198\end{array}$ & $\begin{array}{c}\text { Chi-sq. }= \\
14.57 \\
p=0.5565 \\
\mathrm{~V}=0.2314\end{array}$ & n.a. & n.a. \\
\hline & U2 & $\begin{array}{c}\text { Chi-sq. }= \\
22.18 \\
p=0.1374 \\
\mathrm{~V}=0.2856\end{array}$ & $\begin{array}{c}\text { Chi-sq. }= \\
80.71 \\
p=0.0000 \\
\mathrm{~V}=0.6290\end{array}$ & $\begin{array}{c}\text { Chi-sq. }= \\
12.68 \\
p=0.6959 \\
V=0.2159\end{array}$ & $\begin{array}{c}\text { Chi-sq. }= \\
20.20 \\
p=0.0633 \\
V=0.3147\end{array}$ & $\begin{array}{c}\text { Chi-sq. }= \\
16.28 \\
p=0.1786 \\
\mathrm{~V}=0.2825\end{array}$ & $\begin{array}{c}\text { Chi-sq. }= \\
16.37 \\
p=0.4271 \\
V=0.2454\end{array}$ & n.a. & n.a. \\
\hline
\end{tabular}

The authors, after analyzing the relationships between the helix actors, conducted in-depth interviews with leaders in their scientific fields (at the university) and a practice case study was analyzed to discover their views on the relationship between science and business. An explanation as to why the relationship between scientists and business representatives is weak is provided by the interview results. From the interviews, the authors aimed to determine the characteristics and challenges regarding the relationship between science and business. After listening to the narratives from research participants about their work experiences, three themes became apparent: anchoring to subjectification of ethics, the need for new governance of research, and new establishment. Participant reflections will be used to illustrate on these themes and explore the ways they are related.

Anchoring to subjectification of ethics. Responsibility is mainly related to an individual's morality. However, morality does not exist without a social context, which, in ideal cases, creates a community of 'moral friends' H. M. Engelhardt [47] was concerned about society having a variety of moral perspectives and lacking substantive moral content based on shared beliefs and values. Therefore, when we have too many formal regulations, we become 'moral strangers' instead of 'moral friends' [47,48].

The narratives of the respondents implies 'ambivalent concern', meaning, by enlarging moral obligations of science in connection to society, we threaten to create a phenomenon of 'moral strangers' guided by formal agreements instead of free consensus.

"Academics have long-standing traditions of moral norms such as justice, integrity, consciousness, free will, etc. $<\ldots>$ On the other hand, the business community has corporate social responsibility norms that say the same norms [...] but often business and science apply the same norms differently. Science and business continue to have a different language about ethical norms $<\ldots>$ I doubt whether we need more ethical or moral rules $<\ldots>$ I think that greater regulation would lead to more divergent interpretations and I doubt whether this will help to work better".

"In every case of business research, we sign an agreement that covers many aspects $<\ldots>$ I do not know whether we need some other cooperation. $<\ldots>$ I could not imagine what this could be".We observed that narratives from scientists were imbued with a sense of uncertainty, arising from the lack of critical attitudes towards existing ethical procedures. The lack of critical attitudes tend to support modernist forms of governmentality [49]. Thus, responsible research and innovation guidelines could serve "to create flexible and adaptive governance systems that better manage scientific and social uncertainties" [50].

There is a need for new research governance. The narratives from scientists revealed a contradiction between traditional science governance and open science idea. 
"When it comes to open science, we mainly refer to wider open access to published results. It would be irresponsible to open up raw data to the public in sensitive areas, such as air pollution measures, which are often very complex, and the reader needs competence to understand them".

"Open science needs open industry and business. Quite often, businesses buying research services from a university write a specification in contracts so that the results are only available to the company. This means that the company decides how much and what results will be open. Moreover, business decisions relate to the impact of information on the image and economic factors".

"It is too difficult to have open science when it comes to sensitive data on air pollution and the environmental impact of industry, as every information can trigger a major debate and have a negative impact on the company's image and even on the economic aspects".

"Knowledge is a competitive advantage for business, so companies are reluctant to disclose information".'Modern governance' implies an attempt to shape individual and collective behavior performed by rationalities or discourses, and not by individuals or classes of individuals. Therefore, in order to study modern governance, we have to study how different forms of rationalities, regarding responsibility in science, are conceptualized and justified, and to whom the practice of responsibility is distributed [9]. Cannella and Lincoln note that the ethics discussion (within critical social science) can be interpreted as a form of governmentality; meaning, any construction of ethics represents a form of governance [49].

There is a need for a new establishment. There is a strong narrative about the need for radical scientific changes, to have successful open research and innovation.

"Open science is possible to develop alongside with artificial intelligence. When we have huge and complex data, where analysis is based on billions of combinations, we need more than simple counting".

"We need more establishments with an entrepreneurial approach which would not replace traditional science model, it can be complimentary".

"Open science can serve as technical platform for very complex interdisciplinary projects $<\ldots>$ it is important to give a task and standard".

We looked into several recently established organizations (considered "science clusters") and/or associations that offer multiple memberships. One instrumental case study involving a robotics cluster presented a unique and challenging form of teamwork. Its objectives included incentives for inventors, ensuring cooperation between science and business, linking the development and introduction of robots in the economics field and creative industries, while providing a high quality environment for the development of innovations. Representatives from the robotics cluster participated in an exhibition comprised of young scientists. The team won an award for their robot prototype-manipulator.The manipulator was designed, considering the technical requirements specified by the company UAB "Schmitz Cargobull Baltic". While developing this innovative project, students gained interdisciplinary knowledge and teamwork skills, and learned how to prepare the design documentation. The lecturers (coordinating the project) strengthened the relationships between the social partners.

Robotics cluster participants focused on the information sharing process, networking, and working differently than traditional teams. They discovered that networking and information sharing is easier to develop due to enablement from ICT systems for small platforms, and other sharing spaces. They discovered that the most difficult challenge is in the development of team working.

Many experts of this cluster note that contemporary organizations have to create a team-working spirit that is different from the traditional one. Moreover, they have to find different narratives [46]. Cluster participants focused on constructing an 'incubator' of shared value partnerships instead of a serial-process driven system; it is based on the following principals: 
- External activity (combination of internal and external activity) vs. internal focus (focus on trust, cohesion, and effective work processes).

- Extensive ties (internal ties supplemented with both strong and weak ties outside the team) vs. ties to other members (efforts to build close ties and strong identity).

- Expandable tiers (core, cooperation, and outer-net tiers) vs. one tier (one structural tier: team versus environment).

- Flexible membership (movement across tiers-and in an out of team) vs. stable membership (leaders and members).

Mechanism for execution, i.e., coordination among tiers vs. coordination among individuals [51].

The robotics cluster noted the importance of a national innovation ecosystem. Following the worldwide trend for automation and digitalization of industrial processes, defined as Industry 4.0, the governments of both countries have launched national committees to cultivate industrial competitiveness. In Lithuania, this committee was later integrated into a larger national platform for digitization of industry, called "Pramone 4.0 ". The main goal of the platform is to endorse the digitalization of business industrial processes at the national level. To ensure a purposeful, continuous development of Industry 4.0 in Lithuania, "Lithuanian industry digitalization roadmap 2019-2030" [52] was further introduced, setting a strategic direction, and identifying necessary strategic actions. "Working groups of Lithuanian Industry 4.0 platform after a series of round table debates and analysis of technological foresights (mainly High level strategy group on Industrial technologies under the European Commission review of key enabling technologies (KETs), EC (2016) study on advanced manufacturing technologies, Factories of the Future roadmap, Robotics 2020 Multi-annual roadmap, foresights by Imperial College London, Gartner and McKinsey group insights), have agreed on the certain list of technologies that will have the biggest impact on the digitalisation of Lithuanian industry until 2030" [52] (p. 11).

\section{Discussion}

In the updated version of the Global Competitiveness index (GCI), innovation not only involves technological innovation, but, in a broader notion, an "ecosystem" (environment) conducive to the generation of ideas and their implementation, in the form of new products, services, and processes in the global marketplace [53].

Thus, the concept of responsible research and innovation go beyond the delimitation between good and bad, correct and incorrect; it also involves complex judgements, taking into consideration all that might happen.

The implementation of an approach based on responsible innovation in the industrial ecosystem is currently seen as an opportunity to launch the process. The COVID-19 pandemic has a particular role to play in the interdisciplinary debate on the protection of the industrial ecosystem; the scientific discussion should be strengthened and continued across the globe. We should note that the scientific discussion is actually advancing. For example, Ranjbari, et al. analyzed three pillars of sustainability in the wake of COVID-19 and noted that, "the COVID-19 pandemic has immensely impacted the economic, political, and environmental pillars of sustainability in human lives" [4] (p. 1). We share the view of other researchers that theoretical applications and practical conclusions should be provided for governments, authorities, practitioners, and policymakers to alleviate the negative impacts of the pandemic on sustainable development and to realize the sustainability transition opportunities post-COVID-19. There are discussions on how to identify action priority areas post-COVID-19 to fulfill the sustainable development goals (SDGs) at the country level (i.e., basic needs; economic growth and industrial infrastructure; social sustainability; environmental sustainability) $[5,54]$.

As a follow-up to this debate, we conducted further research, where we combined several strategies and perspectives. The cases we studied illustrated the application of ethics and responsibility combined with value-based collaborations, using ideas from different sources, and incubating small, agile teams to test them. The Quadruple Helix 
model indicates that, when considering an environment (conducive to idea generation and innovation), we should also consider collaboration among businesses, societies, governments, and universities (science sector). This approach is in line with what was presented by Bellandi et al. [44], who noted that, if there is good cooperation between these actors in the ecosystem, it is conducive toward the smooth implementation of innovations, including social innovation. Research on social capital for respondents in Poland and Lithuania confirmed the findings of Hadjielias et al. [28], specifically that a high level of social capital, especially trust, facilitates the entrepreneurial process. Moreover, the authors agree with Koottatep et al. [35], in that, by analyzing (and understanding) the interactions of company innovators with stakeholders, i.e., key partners, we can better understand the innovation process for development. This will allow us to develop responsible research and innovation (RRI) methods, i.e., research that will not only help a business make profits, but also contribute to the common good of society and science.

Our research narrative shows that RRI lacks clarity in how it could be practically applied in traditional research. Nevertheless, RRI is relevant in innovations, because, in designing technological solutions, we often encounter the Collingridge dilemma, when the full functionality and impact of a technology cannot be easily predicted until it is sufficiently developed and widely used, after which time it is difficult to make any substantial changes. Therefore, research participants noted that we need strong transparency to implement RRI. This is all the more important because, as the authors' research indicates, there is often a lack of trust in stakeholders; when there is trust, there is cooperation, and interdependencies between ecosystem stakeholders are stronger. The authors therefore agree with the findings by Nordberg et al. [43], who noted the important of innovations emerging as a result of collaboration between all helices. An example of such collaboration is, as pointed out by Gupta and Rubalcaba [55], collaboration between universities and startup enterprises.

The study showed that scientists have different opinions about the roots of RRI in today's science and industry. Regarding industrial representatives, responsibility is often understood as commitment to the client and legal norms; for scientists, it is about a commitment to the academic ethics code. Therefore, both scholars and business people raise questions about desirable attitudes of responsible innovation and desire clear definitions on the types of responsibilities to be fulfilled by innovators. We see a problem, because this point of view, which seeks to sort and define the scope of responsibility, aims to narrow down responsibility based on personal interests. According to the authors, however, when innovating, it is important to be guided by the philosophical approach of responsibility to each person, as having one "piece" of responsibility (more so than everybody else). Responsibility that carries such a meaning encouraging discussions about the welfare of society and nature; responsibility is then understood as more than just an absence of guilt. In order to develop such responsibilities, the role of the university is crucial [8] as it shows a link between responsible technology application and personal ethics.

In future research, we recommend examining the new variables of RRI cooperation and integration in the industrial ecosystem by adapting the Fivefold Helix model. The sustainable development component can be strengthened further; thus, the "fifth spiral" could be applied in future investigations. In future research projects, the authors also intend to expand the research geography to include EU countries.

It should be added that the literature should continue to explore the regulatory effect of advanced technology usage policies.

\section{Conclusions}

The research narratives conducted in this article suggest that cooperation between stakeholders from different sectors, i.e., business, science, government, and civil society, is necessary for social innovations to be implemented, and to allow innovate ideas to run more smoothly. In this study, the relationship between universities (more broadly the scientific community) and the business community in two Central and Eastern European countries, i.e., Lithuania and Poland, were investigated. 
The narrative of this paper suggests that people from different sectors, i.e., university and industry, have become increasingly aware of the emergence of science and industry cooperation as an 'open platform' enlarged with society and policy. They note the problem of making research public and transparent in the new mode of cooperation; however, they articulate RRI as a framework of shared taxonomy for application of ethics and responsibility. Regarding RRI approach extension: RRI is becoming an umbrella concept for science and business cooperation, based on social responsibility and open innovations. RRI is challenging the traditional approaches toward co-operation, product commercialization, disclosing information, etc.

As a result of our analysis, we found that the main challenges are related to new developments in science governance, which enable one to go outside the traditional approach, particularly when ethics are addressed to particular methodological rules of grand narratives. The research shows that, at times, there are contradictions in understanding the RRI between researchers/scientists and scientific policymakers (regarding the value of public research and innovation, science policy is considered a 'privileged role' in driving economic growth). Moreover, in business, we need to enlarge ethical considerations far beyond client satisfaction or financial obligations. Hence, the Quadruple Helix model was used to analyze the relationships in the innovation ecosystem.

The research results indicated that, in Poland and Lithuania, there is a statistically significant relationship between trust in government and its activities and willingness to cooperate (or rather, willingness to engage in pro-social activities). The study indicated that, in Poland, there is a strong relationship between government activity and trust in government and public officials; it highlighted the importance of society feeling that their voices matter; and revealed that civic engagement can benefit other people. Unfortunately, the majority of respondents do not trust the government, which is not conducive to people feeling that their voices matter. Moreover, respondents believed that the government takes 'little action' regarding matters that benefit society and the common good of, i.e., other members of the ecosystem. Such an assessment of actions from the government and public officials will certainly not encourage enterprises, universities, or society (especially businesses) to cooperate with the government in implementing innovations. In Lithuania, on the other hand, such findings mainly concern the relationship between the government and universities. There is a strong relationship between the government and universities, specifically concerning trust in public officials and confidence in the integrity of academics and their performance.

According to the research, the same is true for cooperation among companies. In both studied countries, it was found that, if there is trust in public officials, then companies are more inclined to implement actions related to helping others. Thus, it can be concluded that this increases the propensity of implementing social innovations. Similarly, strong relationships and statistically significant correlations were found in relationships with the public. When local communities are willing to engage in community service and volunteering, then companies are willing to engage in social innovation. It also works the other way round, i.e., when society perceives that companies engage in such activities, then society feels that their activities make sense. It can be concluded that social capital fosters cooperation between companies, society, and government. It can therefore be presumed that, as pointed out by Mazzucchelli et al. [27], its existence also fosters the development and strengthens the competitiveness of companies.

The authors in this study also proved that there was a lack of dependence/strong relationship between firms and universities in the two studied countries. There was also no statistically significant relationship between trust in universities and innovations undertaken by companies. Although a significant number of respondents believed that university staff are honest, this does not translate into cooperation between science and companies.

In-depth interviews conducted by the authors revealed a strict localized attitude toward responsibility, namely, industrial representatives believe that scientists should be responsible for their field, while industrial representatives should take responsibility for 
their own field. This viewpoint conflicts with the ecosystem approach, when a company is viewed not as a separate firm, but as a member of a business ecosystem, with participants who are interdependent and primarily governed by self-regulated behavior. However, the cluster case study provided rather optimistic insights. Cluster participants focused on constructing an 'incubator' of a shared value partnership, where ideas were gathered from many different sources, and small, agile teams were incubated, to test and iterate them on the application of ethics, responsibility, and communication.

The conclusions presented by the authors regarding the relationship between business and universities in Poland and Lithuania, i.e., in the region of Central and Eastern Europe, are beneficial for science. The authors indicate that there is still no ecosystem approach to the implementation of social innovation. In this region of Europe, there are still barriers to the existence of such an approach, especially between companies and universities. Furthermore, new activities could be identified for science-business-public-policymakers to strengthen the implementation of RRI understanding in the industrial ecosystem, i.e., internal university activities and expertise; STEM; engaging commercial stakeholders in research and social media; and expressing the values of RRI in the industrial ecosystem to all actors.

Admittedly, the study carried out in this paper has some limitations, including generalizing the conclusions obtained here to the entire population. Nevertheless, it seems that, with the development of RRI embedded within the Quadruple Helix model, we are moving toward a new kind of cooperation between science and business, a peculiar small social contract, where both sides agree on revising their fundamental principles, such as freedom or capital, in the name of a new vision of welfare and well-being.

Author Contributions: Conceptualization, R.N. and A.V.; methodology, R.N.; software, R.N.; validation, R.N. and A.V.; formal analysis, R.N. and A.V.; investigation, R.N. and A.V.; resources, R.N. and A.V.; data curation, R.N. and A.V.; writing-original draft preparation, R.N. and A.V.; writingreview and editing, R.N. and A.V.; visualization, R.N. and A.V.; supervision, R.N. and A.V.; project administration, R.N. and A.V.; funding acquisition, R.N. and A.V. All authors have read and agreed to the published version of the manuscript.

Funding: The project is co-financed within the framework of the program of the Minister of Science and Higher Education under the name "Regional Excellence Initiative" in the years 2019-2022; project number 001/RID/2018/19; the amount of financing PLN 10,684,000.00.

Conflicts of Interest: The authors declare no conflict of interest.

\section{References}

1. Ai-Youbi, A.O.; Al-Hayani, A.; Bardesi, H.J.; Basheri, M.; Lytras, M.D.; Aljohani, N.R. The king abdulaziz university (KAU) pandemic framework: A methodological approach to leverage social media for the sustainable management of higher education in crisis. Sustainability 2020, 12, 4367. [CrossRef]

2. Barbier, E.B.; Burgess, J.C. Sustainability and development after COVID-19. World Dev. 2020, 135, 105082. [CrossRef]

3. Elliott, R.J.R.; Schumacher, I.; Withagen, C. Suggestions for a Covid-19 post pandemic research agenda in environmental economics. Environ. Resour. Econ. 2020, 76, 1187-1213. [CrossRef]

4. Ranjbari, M.; Shams Esfandabadi, Z.; Zanetti, M.C.; Scagnelli, S.D.; Siebers, P.-O.; Aghbashlo, M.; Peng, W.; Quatraro, F.; Tabatabaei, M. Three pillars of sustainability in the wake of COVID-19: A systematic review and future research agenda for sustainable development. J. Clean. Prod. 2021, 297, 126660. [CrossRef]

5. Ranjbari, M.; Shams Esfandabadi, Z.; Scagnelli, S.D.; Siebers, P.-O.; Quatraro, F. Recovery agenda for sustainable development post COVID-19 at the country level: Developing a fuzzy action priority surface. Environ. Dev. Sustain. 2021, 3, 1-28. [CrossRef]

6. Carayannis, E.G.; Barth, T.D.; Campbell, D.F. The Quintuple Helix innovation model: Global warming as a challenge and driver for innovation. J. Innov. Entrep. 2012, 1, 2. [CrossRef]

7. Leydesdorff, L.; Etzkowitz, H. Can 'the public' be considered as a fourth helix in university-industry-government relations? Report on the Fourth Triple Helix Conference, 2002. Sci. Public Policy 2003, 30, 55-61. [CrossRef]

8. Wang, M.X. Construction of "responsibility-oriented" education system of corporate social responsibility in colleges. J. Interdiscip. Math. 2018, 21, 369-376. [CrossRef]

9. Glerup, C.; Horst, M. Mapping 'social responsibility' in science. J. Responsible Innov. 2014, 1, 31-50. [CrossRef]

10. Nordmann, A. Responsible innovation, the art and craft of anticipation. J. Responsible Innov. 2014, 1, 87-98. [CrossRef] 
11. Van den Hoven, J. Options for Strengthening Responsible Research and Innovation. Report of the Expert Group on the State of Art in Europe on Responsible Research and Innovation; European Commission, Directorate-General for Research and Innovation: Bruxelles, Belgium, 2013.

12. Côté, R.; Yong, G. Diversity in industrial ecosystems. Int. J. Sustain. Dev. World Ecol. 2007, 14, 329-335. [CrossRef]

13. Hodgson, G.M. Taxonomic Definitions in Social Science, with Firms, Markets and Institutions as Case Studies. J. Inst. Econ. 2019, 15, 207-233. Available online: https:/ / search.proquest.com/docview/2190943219 (accessed on 22 August 2021). [CrossRef]

14. Van de Poel, I.R.; Sand, M. Varieties of responsibility: Two problems of responsible innovation. Synthese 2018, $198,4769-4787$. [CrossRef]

15. Feyerabend, P. Against Method; New Left Books: London, UK, 1975.

16. Fuller, S. The Governance of Science: Ideology and the Future of the Open Society; Open University Press: Buckingham, UK, 2000.

17. Norkus, Z. Akademinis mokslas ir demokratija. Politologija 2001, 4, 3-52.

18. Von Hippel, E. Inovaciju Demokratèjimas; Lietuvos Inovaciju Centras: Vilnius, Lithuania, 2010.

19. Cope, J. Entrepreneurial learning from failure: An interpretative phenomenological analysis. J. Bus. Ventur. 2011, 26, 604-623. [CrossRef]

20. Carolan, M.S. Science, expertise, and the democratization of the decision-making process. Soc. Nat. Resour. 2006, 19, 661-668. [CrossRef]

21. Nielsen, N. Atradimai Kitaip. Nauja Tinklu Mokslo Era [Translation into Lithuanian from Reinventing Discovery: The New Era of Networked Science]; Princeton University Press: Princeton, NJ, USA, 2014.

22. Kühn, I.K. Enhancing social competence for disadvantaged youth in pre-vocational education: Model development through design-based research. J. Res. Vocat. Educ. Train. 2017, 4, 346-368. [CrossRef]

23. Zandvoort, H. Preparing engineers for social responsibility. Eur. J. Eng. Educ. 2008, 33, 133-140. [CrossRef]

24. Schönherr, N.; Martinuzzi, A.; Jarmai, K. Towards a business case for responsible innovation. In Responsible Innovation, SpringerBriefs in Research and Innovation Governance; Jarmai, K., Ed.; Springer: Berlin/Heidelberg, Germany, 2020; pp. 85-97. [CrossRef]

25. Martinuzzi, A.; Blok, V.; Brem, A.; Stahl, B.; Schönherr, N. Responsible research and innovation in industry-Challenges, insights and perspectives. Sustainability 2018, 10, 702. [CrossRef]

26. Goodman, J.; Korsunova, A.; Halme, M. Our collaborative future: Activities and roles of stakeholders in sustainability-oriented innovation. Bus. Strategy Environ. 2017, 26, 731-753. [CrossRef]

27. Mazzucchelli, A.; Chierici, R.; Tortora, D.; Fontana, S. Innovation capability in geographically dispersed R\&D teams: The role of social capital and IT support. J. Bus. Res. 2021, 128, 742-751. [CrossRef]

28. Hadjielias, E.; Dada, O.; Eliades, K. Entrepreneurial process in international multiunit franchise outlets: A social capital perspective. J. Bus. Res. 2021, 134, 13-28. [CrossRef]

29. Pirson, M.; Malhotra, D. Foundations of organizational trust: What matters to different stakeholders? Organ. Sci. 2011, 22, 1087-1104. [CrossRef]

30. Mu, J.; Peng, G.; Love, E. Interfirm networks, social capital, and knowledge flow. J. Knowl. Manag. 2008, 12, 86-100. [CrossRef]

31. Sharma, D.D.; Blomstermo, A. The internationalization process of born global: A network view. Int. Bus. Rev. 2003, 12, 739-753. [CrossRef]

32. Argentiero, A.; Cerqueti, R.; Sabatini, F. Does social capital explain the Solow residual? A DSGE approach. Struct. Chang. Econ. Dyn. 2021, 58, 35-53. [CrossRef]

33. Nagaj, R.; Szkudlarek, P. The change in the perception of the state by students in Poland and Lithuania in the context of research on social capital. Econ. Res.-Ekon. Istraživanja 2019, 32, 1298-1319. [CrossRef]

34. Lubberink, R.; Van Blok, V.; Van Ophem, J.; Omta, O. Lessons for responsible innovation in the business context: A systematic literature review of responsible, social and sustainable innovation practices. Sustainability 2017, 9, 721. [CrossRef]

35. Koottatep, T.; Sukavejworakit, K.; Virasa, T. Roadmap for innovators in the process of innovation for development. Sustainability 2021, 13, 84. [CrossRef]

36. Gurzawska, A.; Mäkinen, M.; Brey, P. Implementation of responsible research and innovation (RRI) practices in industry: Providing the right incentives. Sustainability 2017, 9, 1759. [CrossRef]

37. Lepsius, O. Georg Jellinek's theory of the two sides of the state ("Zwei-Seiten-Lehre des Staates"). In The Normative Force of the Factual. Law and Philosophy Library; Bersier Ladavac, N., Bezemek, C., Schauer, F., Eds.; Springer: Berlin/Heidelberg, Germany, 2019; Volume 130. [CrossRef]

38. Denning, S. Storytelling and Post-Modernism. 2016. Available online: http://www.stevedenning.com/Business-Narrative/ storytelling-and-post-modernism.aspx (accessed on 5 July 2018).

39. Lyotard, J.F. The Postmodern Condition: A Report on Knowledge; University of Minnesota: Minneapolis, MN, USA, 1979.

40. Czarniawska, B. The uses of narratology in social and policy studies. Crit. Policy Stud. 2010, 4, 58-76. [CrossRef]

41. Czarniawska, B. Narratives in Social Science Research; Sage: Thousand Oaks, CA, USA, 2004.

42. Linde, C. Narrative and social tacit knowledge. J. Knowl. Manag. 2001, 5, 160-171. [CrossRef]

43. Nordberg, K.; Mariussen, Å.; Virkkala, S. Community-driven social innovation and quadruple helix coordination in rural development. Case study on LEADER group Aktion Österbotten. J. Rural Stud. 2020, 79, 157-168. [CrossRef]

44. Bellandi, M.; Donati, L.; Cataneo, A. Social innovation governance and the role of universities: Cases of quadruple helix partnerships in Italy. Technol. Forecast. Soc. Chang. 2021, 164, 120518. [CrossRef] 
45. Grootaert, C.; Narayan, D.; Jones, V.N.; Woolcock, M. Measuring Social Capital: An Integrated Questionnaire; World Bank Working Paper No. 18; The World Bank: Washington, DC, USA, 2004; Available online: https:/ / openknowledge.worldbank.org/bitstream/ handle/10986/15033/281100PAPER0Measuring0social0capital.pdf?sequence=1 (accessed on 20 August 2019).

46. Barge, J.K. Antenarrative and managerial practice. Commun. Stud. 2004, 55, 106-127. [CrossRef]

47. Engelhardt, H.T. The Foundations of Bioethics, 2nd ed.; Oxford University: New York, NY, USA, 1996.

48. Laabs, C.A. The Community of nursing: Moral friends, moral strangers, moral family. Nurs. Philos. Off. J. Int. Philos. Nurs. Soc. 2008, 9, 1-17. [CrossRef]

49. Cannella, G.S.; Lincoln, Y.S. Ethics, research regulations, and critical social science. In The Sage Handbook of Qualitative Research, 5th ed.; Denzin, N.K., Lincoln, Y.S., Eds.; Sage: Thousand Oaks, CA, USA, 2018; pp. 83-96.

50. Van Oudheusden, M. Where are the politics in responsible innovation? European governance, technology assessments, and beyond. J. Responsible Innov. 2014, 1, 67-86. [CrossRef]

51. Ancona, D.; Bresman, H.; Kaeufer, K. The comparative advantage of X-teams. In Inventing the Organizations of the 21st Century; Malone, T.W., Laubacher, R., Scott Morton, M.S., Eds.; The MIT Press: Cambridge, MA, USA, 2003; pp. $283-317$.

52. Ministry of Economy and Innovation. Pramone 4.0. Lithuanian Industry Digitalization Roadmap 2019-2030. Vilnius. 2018, pp. 1-17. Available online: https:/ /industrie40.lt/wp-content/uploads/2019/03/Lithuanian-Industry-Digitisation-Roadmap-20 19-2030_final.pdf (accessed on 29 July 2021).

53. The Global Competitiveness Report 2015-2016; World Economic Forum: Geneva, Switzerland, 2015; Available online: Reports. weforum.org/global-competitiveness-report-2015-2016/ (accessed on 20 July 2021).

54. Nagaj, R.; Žuromskaite, B. Tourism in the Era of Covid-19 and Its Impact on the Environment. Energies 2021, 14, 2000. [CrossRef]

55. Gupta, V.; Rubalcaba, L. University libraries as open innovation partners: Harnessing hidden potential to foster global entrepreneurship. J. Acad. Librariansh. 2021, 102432. [CrossRef] 